\title{
Progesterone Receptor Status 0
}

National Cancer Institute

\section{Source}

National Cancer Institute. Progesterone Receptor Status O. NCI Thesaurus. Code C147856.

An immunohistochemical result of 0 for progesterone receptor expression that is considered negative for expression. 